Tér és Társadalom 23. évf. 2009/2. 201-211. p.

Tér és Társadalom

XXIII. évf. 2009 2: 201-235

\title{
KITEKINTÖ
}

\section{AZ OROSZ VÁROS}

\author{
(The Russian City)
}

\section{ENYEDI GYÖRGY}

Kulcsszavak:

urbanizáció orosz városfejlödés szovjet városok poszt-szovjet urbanizáció

A cikk azt a feltételezést vizsgálja, hogy az orosz urbanizáció minden korban sajátos, endogén pályát követett. Ennek bizonyitására áttekinti a városhálózat kibontakozásának s müködésének folyamatát a kezdetektöl 1917-ig; jellemzi a szovjet idöszakot (amidön a mai városhálózat zöme kialakult) és a posztszovjet idöszakot. Valószínüsiti, hogy az orosz urbanizáció továbbra is sajátos pályán haladva követi az európai urbanizáció szakaszait.

\section{Bevezetés}

E tanulmány része annak az átfogó vizsgálatnak, amely napjaink (azaz a globalizáció korának) urbanizációját kísérli meg típusokba sorolni, az urbanizációs folyamatok mechanizmusát feltárni, a típusok alapvető jellemzőit meghatározni. A világ urbanizációs folyamatának szakaszokra bontása régóta foglalkoztat (Enyedi $1984 ; 1988 ; 2003)$. E szakaszokat a nagy gazdasági ciklusokhoz kötöttem, feltételezve, hogy mindegyik ciklus - az ipari forradalom, az érett iparosítás, a posztindusztriális fejlődés, a globalizáció gazdasága - más-más jellegü városfejlődést indít el, amidőn a Föld történelmi városhálózatát különböző földrajzi helyeken, különböző időkben eléri. Más szerzők a Föld urbanizációs pályáját a kezdetektől, több ezer év történetén keresztül elemzik és a társadalom-történet szempontjából bontják szakaszokra (Eisenstadt-Shachar 1987). Kelet- és Közép-Európa mai urbanizációs pályájának sokan fontos jellemzőjének tartják, hogy több évtizedig az államszocialista politikai s gazdasági rendszer keretében fejlödött, emiatt is különbözött az európai piacgazdaságok városfejlődésétől és ez a különbség ma is jelentôs (Csaba 2006; Stanilov 2007). Az orosz urbanizáció azonban egyetlen történelmi korszakban sem illeszkedett az európai urbanizációs szakaszokba. Nem csak a szovjet korszakban, hanem az ipari forradalom idején sem, a középkori városhálózat kialakulása idején sem. Megfogalmazódik tehát az a hipotézis, hogy az orosz városfejlődés endogén jellegü. Nemcsak a szovjet korszak urbanizációja volt egyedi - ez eléggé kézenfekvő: hanem a megelőző korok urbanizációja is, és a jelen, többnyire poszt-szocialistának nevezett korszaké is. Az orosz civilizáció része az európai 
keresztény civilizációnak, ám a 18. századig a (nyugati) keresztény Európával vajmi kevés kapcsolata volt. A hosszú távú európai urbanizációs pályák ugyan negyven évre megbomlottak Kelet-Közép-Európában, de nem tüntek el. A városlakók emlékezete is megőrizte ezeket, $\mathrm{s}$ a rendszerváltozás után a visszailleszkedés azonnal megkezdődött. Oroszországban a visszailleszkedés a rendszerváltozás után a sajátos orosz úthoz történt, az endogén fejlődés tovább folytatódott, igaz, erősödő globalizációs hatások mellett. E rövid dolgozat az egyedi, endogén orosz városfejlödés hipotézisét kísérli meg bizonyítani, négy történelmi keresztmetszetben: a pre-kapitalista, az ipari forradalom, a szovjet korszak és a poszt-szocialista fejlődés időszakában. Nem lehet célunk a részletes leírás, csupán a ,saját út" bizonyítékainak felvázolása.

\section{Az orosz városhálózat kialakulása ${ }^{l}$}

A mai Oroszország területén a városok kialakulása bő 2000 éves múltra tekint vissza. Az első városok délen: a Fekete-tenger mentén, a Kaukázus vidékén és Közép-Ázsiában jelentek meg - ám ez még nem orosz városodás volt. A Fekete-tenger déli-délnyugati medencéjében a klasszikus - görög, majd római - városfejlỏdés is megjelent. Közép-Ázsia első városai pedig a Kelet-Ázsia-Római Birodalom kereskedelmi útvonal állomásai voltak, a termékeket összegyủjtő, továbbító s az útvonal katonai védelmét ellátó funkciókkal. Az orosz urbanizáció csak valamikor a 8-9. században vette kezdetét - ekkor jelentek meg az első szláv városok az orosz síkságon. E városok kereskedelmi állomások voltak a Skandináviát Bizánccal összekötő útvonalak mentén. Ezeket az útvonalakat a Fekete-tengerre kifutó folyók völgyei vezették Észak Európa felé. Az első városalapítók vikingek voltak. Egy sor város„államot” hoztak létre: ilyen volt Kijev, Novgorod és Szmolenszk. Ezek a városok a kereskedök árugyúitő-szétosztó helyei, meg az áru vámok begyüjtỏ helyei voltak. A városokba az útvonalak mentén élő szláv lakosság is beköltözött, és végül a vikingek is átvették az orosz nyelvet. Ebböl a laza városláncolatból emelkedett ki és vált a legfontosabb csomóponttá Kijev. A középkorban egy egész történelmi korszakot neveznek a Kijevi Oroszország idöszakának. Kijev helyzeti enegiáinak köszönhette kiemelkedését: az erdő-övezet és a sztyeppe határán fekvén, a Dnyeper folyó által Bizánccal is összeköttetvén kiváló árucsere helynek bizonyult. A 9. században megjelent a (keleti) kereszténység, azóta írott története is van a Kijevi Oroszországnak. A 12. században már kb. 300 város volt a területén - északon az erdỏs sztyeppe, délen a Fekete-tenger, keleten a Volga felső folyásáig terjedtek el. Az orosz urbanizáció bölcsője tehát jórészt a mai Ukrajna területén alakult ki. A Kijevi Nagyhercegség fontos volt ugyan, ám korlátozott hatáskörü. A valóságban valamennyi számottevő város kis önálló hercegségként müködött. A feudális szétdaraboltság hasonlított a korabeli Nyugat-Európáéhoz (miközben Közép-Európát nagy, központosított állammá szervezett birodalmak jellemezték). A nyugat-európai és az orosz feudális szétdaraboltság azonban egy szempontból nagyon különbözött: ez a városok autonómiája és 
társadalmi szerkezete. Nyugat-Európában a városokat már a középkorban a feudális nagybirtokkal való szembefordulás, a városi önkormányzatok autonómiájának kivívása, a szabad polgárság függetlenségének biztosítása jellemezte ${ }^{2}$. Oroszországban (s általában Kelet-Európában) a városok voltak a feudális földbirtokos nemesség központjai, ahonnan a falvak kizsigerelését irányították - egészen a 19. század végi jobbágyfelszabadításig. Kivételt jelentett Novgorod, amely a hosszú távú kereskedelem fontos állomása volt a Kievi Oroszország és a Baltikum német városai között, ezért a kereskedők a város rendkívül fontos társadalmi rétegét jelentették, és a város belső szervezete inkább a Hanza városokéra hasonlított.

A tatárjárást - 1237 és 1240 között - a Kijevi Oroszország is megszenvedte. A pusztítás oly mértékủ volt, hogy a meggyengült Kijevi állam nyugati része a LengyelLitván Birodalom részévé vált. Egy idöre e területen érvényesült az európai városfejlődés hatása, ami az ukrán és fehérorosz városok történelmi városközpontjain ma is látszik. Az orosz városhálózat megmaradt része lassan állt helyre, 1480-ig a tatárok (a Mongol Birodalom) fennhatósága alá került. Az újra önállóvá vált Oroszországban a városok kelet felé: a Volga mentén, Asztrahányig terjeszkedtek. 1700-ban mindössze 300 város volt az ország területén, annyi, mint 450 évvel korábban. Az Orosz Birodalom kialakulása, erős állammá szerveződése, a városfejlődés meglendülése tehát ugyancsak megkésett Európához képest - mindössze bő három évszázad a története. Oroszország állam-modellje a 18. század elsö feléig a mongol despotizmust követte. Az orosz városok nem ismerték meg a reneszánsz szellemét és építészetét vagy a felvilágosodás eszméit. Oroszország a keresztény világhoz tartozott ám az orosz ortodox egyháznak nem voltak kapcsolatai a nyugati kereszténységgel.

A 17. század vége és a 18. század első fele hozott változást az orosz városrendszerben, mindenekelött Nagy Péter cár uralkodása idején. Szentpétervár megalapításával városi kapu nyílt Európa felé, amelyen át beszivárgott az orosz városhálózatba az európai építészet, kereskedelem-szervezés, városi igazgatás számos eleme. Az európai nyitás szándéka olyan erős volt, hogy az 1703-ban alapított Szentpétervárt európai mintákat követő nagyvárossá fejlesztették és Oroszország fövárosává tették. (Moszkva csak a szovjet korszakban kapta vissza fövárosi státuszát.) Nagy Péter uralkodása idején megerösödött a nyugati orosz városok kereskedelmi szerepe, kereskedö társaságok alakultak, és számos külfơldi - föleg német - iparos járult hozzá az orosz városok első modernizációs hullámához. E változásokat több tényezö ösztönözte. A korábban iparosodott, s a gyarmatosítás révén jelentős tőke-felhalmozáshoz jutott Nyugat-Európa érdekelt volt gazdasági kapcsolatainak kelet-európai kibővítésében. Ez az Oroszország nyugati részén fekvő városok kereskedelmi szerepét erösítette. Nagy Péter azért is támogatta a városok kereskedelmi s ipari szerepkörének bővülését, mert az ebből keletkező adók jelentették a cári udvar legfőbb bevételét. Átfogó változásokat hozott Nagy Katalin cárnő uralma a 18. század végén. A városok autonómiát nyertek, polgáraik városi tanácsokat hoztak létre, a városi adók által finanszírozott közszolgáltatásokat maguk szervezték meg - az orosz városhálózat ekkor érkezik meg Európába. A birodalom megszerzi a Baltikumot, a mai Belorusszia városait, a Kaukázuson túli keresztény államok pedig - Perzsiától s a Török Birodalom- 
tól való félelmükben - Oroszország protektorátusa alá helyezik magukat. A szibériai terjeszkedés eléri a Csendes-óceánt, város épül Kamcsatkản, sỏt még Alaszkában is mely tartományt később eladnak az Egyesült Államoknak. Ez időtől kezdve nehéz megkülönböztetni a szó szoros értelmében vett orosz városfejlödést a cári birodalom, majd késóbb a Szovjetunió urbanizációjától. Az orosz (tehát oroszok lakta, az orosz városfejlődést követő) városok benyomultak a Kaukázusontúli s közép-ázsiai területekre, s azok városaival egységbe szerveződő településrendszert hoztak létre.

Az 1811. évi népszámlálás adatai szerint Oroszország lakóinak 4\%-a él a 400 városban - eléggé szerény növekedés a középkor óta. Érdekes megjegyezni, hogy a birodalom 10 legnépesebb városa között - Moszkva és Szentpétervár után - csak két régi orosz várost (Kijev, Nyizsnyij Novgorod) találunk; hat (Vilniusz, Kisinyov, Riga, Tbiliszi, Kazány és Asztrahány) már birodalmi „szerzemény”. A 19. század során 1861-ig, a jobbágyfelszabadításig, a városok fóleg délen, a fỏ mezőgazdasági övezetben gyarapodtak. Ekkor emelkedik ki Odessza kikötője, mely 1867-ben már az ország harmadik legnépesebb városa. Oroszországban a klasszikus kapitalista fejlödésnek mindössze ötven év jut: az 1860-as évektől 1917-ig, a bolsevik forradalomig. Ez a megkésett s rövid fejlödés igen gyors. A városi népesség aránya a 19. század végére megnégyszereződik: 16\%. Nagyléptékü vasút-építkezésekbe fognak, s a külföldi töke is szívesen települ a megnyíló, hatalmas orosz piacra. Két fố iparvidék formálódik ki. Az egyik Moszkvában s tágabb környékén, ahol a textilipar s a hadiipar voltak a vezetó ágazatok. A másik nagy, nehézipari zóna a mai Ukrajna területén alakul ki, a gazdag vasérc- és szénlelőhelyek kiaknázására alapozva. Színvonalas gépipar fejlődik a Baltikumban s megjelenik Baku, a kőolaj városa. A Transz-szibériai vasút megépítése több korábbi, kisebb szibériai kereskedelmi-katonai állomás nagyvárossá fejlődését teszi lehetövé (Omszk, Novoszibirszk, Krasznojarszk).

Ugyanebben a kapitalista városfejlödési periódusban épül ki a gyarmati városhálózat Közép-Ázsiában. Az Orosz Birodalom nem a hagyományos városokat - mint pl. Bokhara vagy Kokand - fejlesztette, hanem újakat épitettek; közülük Taskent 1914-ben Oroszország hatodik legnépesebb városa volt. Ebben a rohamos kapitalizálódásban Moszkva éppen olyan kiemelkedő gazdasági mágnes lesz, mint a 21. század elején, az újrakapitalizálódás idején. Szentpétervár marad az Európa felé nyitás és a cári udvar városa, ám a gazdasági fellendülést Moszkva diktálja. A város lakossága a 20. század első másfél évtizedében évi 16\%-kal növekedett! A faluról betódulók nagy része egyáltalán nem jut lakáshoz, hatalmas társadalmi feszültségek halmozódnak fel.

A bolsevik forradalom ismét Moszkvát teszi fơvárossá. Ezt gazdasági fejlettsége is indokolja, de inkább politikai tényezők játszottak szerepet - az ủj bolsevik hatalom Moszkvában inkább számíthatott tömeg-támogatásra, mint Szentpéterváron. Geopolitikai előnnyel is rendelkezett - messze volt az ellenséges Európa határától. Ezen kívül a szovjet birodalom a második világháborúig befelé fordult, a belső városhálózatot épitette, ebben is kedvezö volt Moszkva földrajzi fekvése. Ahogyan Szentpétervár alapítása az orosz birodalom európai nyitását szimbolizálta, úgy Moszkva újabb fơvárosi szerepe a bezárkózásnak is jelképe lett. 
Az orosz város a szovjet korszakban

A modern orosz urbanizációnak fontos szakasza a háromnegyed évszázadig tartott szovjet korszak. Az államszocialista rendszer alapvető vonásai: a politikában az egypárti diktatúra, a gazdaságban a tervutasításos rendszer $\mathrm{s}$ a piac helyett bürokratikus újraelosztás, a társadalomban egyenlösdi, állami gondoskodás, a nomenklatúra privilégiumai - az urbanizáció egész menetét áthatották. Sajátosság volt az eredeti orosz és a gyarmati városrendszer egybeolvadása. 1992-ig, a Szovjetunió összeomlásáig fennállt a soknemzetiségủ orosz gyarmatbirodalom - míg a világ gyarmati rendszere az 1950-es, 1960-as években felszámolódott. A bolsevik forradalom megóvta a gyarmatbirodalmat: a balti államok ugyan függetlenné váltak, Bukovina és Besszarábia más országokhoz kerültek, ám ezeket a területeket a Szovjetunió a második világháború alatt $\mathrm{s}$ után visszaszerezte. A poszt-szocialista átmenet válságát ugyancsak elmélyítette, hogy együtt járt a birodalom szétesésével, a Szovjetunión belüli gazdasági szálak meglazulásával, és megbontotta a kialakult városhálózatot. Az elmúlt bő másfél évtized nemcsak a városi funkciók alapos változását s ủj urbanizációs szakaszra történő áttérést jelentett, hanem a szovjet-orosz városhálózat csonkulását, $\mathrm{s}$ új városhálózat kialakulását is. Egy sor belsỏ orosz város - pl. Rosztov - egyszeriben határvárossá lett.

A szovjet időszak urbanizációja három szakaszra különíthető el: 1) az 1920-as évek városfejlödése; 2) a sztálini önkény időszaka és 3) az utolsó húsz év sodródása. Medvedkov (1990) csak két időszakot különböztet meg, a sztálini önkényt és a Hruscsov utáni évtizedeket. Én úgy vélem, az 1920-as évek - a kemény politikai diktatúra ellenére - eltérnek a sztálini önkény periódusától. A polgárháború okozta összeomlás után új gazdaságpolitikát vezettek be, hiszen az ország újjáépitése nem nélkülözhette a külföldi tőke s szakemberek bevonását. A várostervezésben is több korszerü, a nyugat-európai és észak-amerikai szociális-avantgarde elméletekre támaszkodó koncepció megvalósitása kezdődött meg. Nem véletlen, hogy az 1920-as években Le Corbusier és több Bauhaus építész jelent meg házaival Moszkvában. Ezt a rövid periódust részben piaci hatások befolyásolták.

A legjelentősebb városnövekedési periódus az 1928-tól kezdődő időszak volt. A városok számának $\mathrm{s}$ népességének legnagyobb növekedése - a városrobbanás idöszaka - 1928 és 1956 közé tehető. A városnövekedés egyértelmủen az iparhoz kötödött, csak az ipar müködtetéséhez feltétlenül szükséges lakásépítéssel, szolgáltatási funk-ciókkal. Ezt a szakaszt a városokban a termelö funkciók abszolút dominanciája, a városgazdaságban a direkt tervutasításos rendszer, a falu-város vándorlások hatósági ellenőrzése és korlátozása jellemezte. Az 1930-as évek gazdaságpolitikájának a fö célja az erőltetett iparositás, mindenekelőtt a nehézipar és a hadiipar fejlesztés volt. A nehézipar jórészt a nyersanyag-lelőhelyekre támaszkodott, tehát kiemelte az Urál vidék, a Don-medence városhálózatát; másrészt a képzett munkaerőt igénylő gépipari városokat a Volga-mentén és Közép-Oroszországban. Ekkor kezdődött meg az ipar jelentősebb kibontakozása Szibériában is. Az iparosítás fó tökeforrását a mezőgaz- 
daság kizsigerelése és az alacsonyan tartott általános bérszínvonal adta. Az 1930-as évek legelején végrehajtott erószakos kollektivizálás a falusi lakosság tömegeit ủzte el földjéról; e kényszervándorlók az olcsó, tanulatlan munkaerőt adták az ipar számára. A kollektivizálás után a kötelezö termék-beszolgáltatás (önkényesen alacsony árakon) jelentette a mezőgazdaságból történő tőkekivonás állandó formáját. A faluról való menekülés oly méreteket öltött, hogy felelevenítettek egy régi cári hagyományt: a városba költözés külön engedélyhez (propiszka) kötését. A harmincas évek városrobbanását torz elemek kísérték: a nehézipar dominanciája, a fogyasztási cikkek roppant hiánya, a mezögazdasági háttér tönkretétele, az infrastruktúrafejlesztés minimális szintje, ami elképesztỏ lakáshiányt eredményezett. Ezt az ellentmondásos urbanizációs folyamatot szakította meg a II. világháború, amely a legfejlettebb, európai szovjet városhálózatban hatalmas pusztítást végzett. A termelö kapacitásoknak az Uráltól keletre történő menekítése viszont jelentősen megerősítette a szibériai és a közép-ázsiai városok iparát.

A második világháborút követő első évtizedben a sztálini modell mit sem változott: az újjáépítésben a hadiipar kapta az elsöbbséget - a Szovjetunió világhatalommá vált, s fegyverkezési versenybe kezdett az Egyesült Államokkal -, s még a korábbiaknál is elhanyagoltabb lett a városok szolgáltató szerepének vagy lakásállományának bövítése. Az 1950-es évek második felétől enyhült a diktatúra szigora, mérséklödött az áruhiány. A fegyverkezési versenynek ,jótékony” hatása volt az oktatási és kutatás-fejlesztési intézmények megerösödésére. Jelentös volt az ipar szerkezeti átalakulása, a gépipari s tudásalapú ágazatok előre törése, mely ismét az európai orosz városokat erősítette.

A Szovjetunió történetének utolsó húsz esztendejében fontos változások kezdődtek. Kibontakoztak a nagyvárosi agglomerációk; a nagyvárosok egy része a posztindusztriális (szolgáltatás-vezérelt) urbanizációs szakaszba lépett át, korlátozott sikerrel. A településhálózatban megerösödtek a nem-orosz szövetségi köztársaságok fövárosai - Alma Ata, Kisinyov, Vilniusz, Minszk és Jereván a leggyorsabban növekvő milliós városok közé tartoztak. A vándorlási ellenőrzés szigorát gyakran felülírták az új ipari munkaerő-igények.

Sajátos vándorlási motívum volt a városok közötti életszínvonal- és ellátási különbség. A jövedelem- és foglalkoztatási különbségek a világon mindenütt a vándorlások fö ösztönzöi között szerepelnek. A Szovjetunióban azonban gyakorlatilag mindenütt álláshoz lehetett jutni, s a bérkülönbségek sem voltak számottevőek. Ugyanakkor nagy volt az áruhiány, alapvető szolgáltatásokhoz sem lehetett hozzájutni. Ennek az enyhítésére széles körben elterjedtek a különféle privilegizált termék juttatások (zárt üzletek, ahol csak a párt- és tanácsi funkcionáriusok vásárolhattak; fontos hadiüzemek belső üzletei, ahol hiánycikkeket lehetett vásárolni). Kiemelt ellátáshoz jutottak a külföldi turisták számára megnyitott városok is. Ezzel egy sajátos hierarchia-rendszer alakult ki a privilégiumokkal rendelkező és nem rendelkező városok között. Oroszország európai részének nagyvárosai váltak az „ellátási” vándorlás fö célpontjaivá. 
Összefoglalva: a szovjet időszak alatt a városok száma Oroszország mai területén háromszorosára nőtt. 1990-ben 2190 város és 4000 városi jellegü település (ezek általában kisebb üzemi-bányatelepi lakótelepek voltak) volt található. Moszkva növekedése - minden korlátozás ellenére - nagyon erős volt, $\mathrm{s}$ a korszak végére Európa egyik legnagyobb mega-városi régiójává vált. Az orosz városrendszer és a Szovjetunió többi területének városrendszere egyetlen hálózatba forrt össze. Ugyanakkor az orosz városoknak nem voltak a szovjet határon átnyúló közvetlen kapcsolatai, még Szentpétervárnak (akkori nevén Leningrádnak) sem, a szomszédos országokkal sem: a városrendszer teljesen befelé fordult.

\section{Az orosz város a 21. század elején}

A rendszerváltozás az orosz gazdaságot nagyon megviselte. A szovjet birodalom államjogi szétesése is nehéz folyamat volt: Oroszország (a többi volt szovjet tagköztársasággal együtt) 1991-ben vált független állammá. A gazdaság visszaesése olyan mértékü volt, hogy a bruttó hazai termék volumene (reálértéken) 1998-ban az 1990. évinek csak 58\%-át tette ki (Horváth 2008). Az elmúlt évtized gyors növekedést hozott, ám a húsz év előtti gazdasági teljesítményt még nem érték el; a növekedés pedig túlzott mértékben függ a földgáz- és köolaj-export áraitól. A rendszerváltozás válságát most utolérte a világgazdasági válság: a városok többségének gazdasága tartós csődbe került. A tudásalapú gazdaság csak néhány városban jelentős ahol már korábban is jelen volt -, pl. Moszkva vagy Novoszibirszk. Érdekes megjegyezni, hogy az elmúlt években ismét megerősödött, s jelentős kutatás-fejlesztési hátteret tart el a hadiipar.

Csökkenö városi népesség. Oroszország egész népessége fogyott az elmúlt 20 évben. Elsődleges ok a természetes fogyás volt. A moszkvai nagyvárosi régiót leszámítva, az 52 nagyvárosi agglomerációban a népesség gyakorlatilag stagnál, a vándorlási nyereség legfeljebb a természetes fogyást egyenlíti ki; a kis- és középvárosokban a lakosság jelentősen csökkent.

A városi népesség csökkenése kis mértékben adminisztrativ változásoknak is következménye. A korábbi tanácsrendszert nem váltotta fel a rendszerváltozáskor azonnal egy egységes új közigazgatási rendszer. Több önkormányzati törvényt is hoztak, a legutóbbit 2004-ben, melyeket a hatalmas ország különböző régióiban nem egyformán alkalmaztak. Sajátos az orosz szerzők (Molodikova-Makhova 2007; Artobolevszkij et al. 2008) által „,adminisztratív pluralizációnak” nevezett jelenség. Ez azt jelenti, hogy egy sor (kb. 350), tartós válságba került kisebb város falusi jogállásúvá minösítette magát. Ezzel különböző előnyökhöz jutottak: az orvosok és pedagógusok falusi pótlékot kapnak, alacsonyabbak a közszolgáltatási díjak, adókedvezmények járnak a falusi lakosoknak, egyszerübb a földterület privatizálása. A faluvá vált városok összes népessége 3 millió fö, ennyivel csökkent tehát adminisztratív változások miatt a városi lakosság. Olyan különös helyzet is elóállt, hogy a Burját Autonóm Körzetben mind a négy város faluvá minősítését kérte -, van 
tehát egy eléggé nagyterületű közigazgatási egység, ahol - közigazgatási értelemben - egyetlen város sincs.

Az orosz városok térképén egy sor új városnév jelent meg 1994-ben. Ezek a városok már régen léteztek, de hadiipari jellegük miatt nemcsak a külföldiek előtt maradtak zárva, hanem a szovjet állampolgárok sem látogathatták - csak hivatalos kiküldetésben. Ezeknek a zárt városoknak még a nevük sem szerepelt semmilyen statisztikai kiadványban, és térképeken sem. Általában kisebb városok voltak, de volt közöttük középváros is, például Zseleznogorszk vagy Novouralszk. Úgy tünik, máig maradtak különleges övezetek és zárt, szigorúan titkos városok Oroszországban (Lappo-Poljan-Szelivanova 2007, 389).

$\mathrm{Az}$ orosz városrendszer átalakulását alapvetően befolyásolta a piaci viszonyok megjelenése, ezzel a földrajzi fekvésből vagy a népesség szakképzettségéből eredő gazdasági előnyök és hátrányok is. A globális gazdasági hatásokra a fejlett nagyvárosi térségek szintén érzékennyé váltak, de az orosz városrendszer egészére még kevés a közvetlen hatásuk. Az egész orosz városhálózatban érzékelhető a népesség déli és nyugati irányba történő vándorlása. Érthető, hogy sokan törekednek a kedvezőbb éghajlatú, nagyobb település-sủrủségű, fejlettebb infrastruktúrájú régiók felé. Kétszáz év szibériai gyarmatosítása, oroszajkú lakossággal történő betelepítése mely sem a cári Oroszországban, sem a Szovjetunióban nem volt önkéntes - kezd visszafordulni. Szibéria népességének 5\%-át, a Távol-Kelet pedig 16\%-át vesztette el 1989 és 2003 között; ugyanakkor Dél-Oroszország népessége 12\%-kal növekedett (egész Oroszországé 1,3\%-kal csökkent). Az egész településrendszeren belül hallatlan méretủ differenciálódás ment végbe: a két vezető (moszkvai és szentpétervári) nagyvárosi régión kívül megerösödött néhány közép-oroszországi nagyváros ám a helyi központ kisvárosok többsége, különösen a kedvezőtlen éghajlatú övezetekben - zuhanásszerüen leszakadt.

Oroszország népességének 73,3\%-a élt városokban 2006-ban, ami megfelelt a fejlett európai országok átlagának. Ám ez csak mennyiségi hasonlóság, az orosz városoknak sok a sajátos vonása. Elöször is, ez a városhálózat rendkívül fiatal. Az összes város kétharmada a 20. század „terméke”, és kb. 400 város mindössze 40 éve nyert városi jogállást. A 76 negyed milliónál népesebb város közül csupán hét régebbi kétszáz évesnél (Nefjodova-Poljan-Trejvis 2001). A nagyvárosi agglomerációk kialakulása is nagy késedelemmel, a 20. század közepén vált elterjedtté. Az pedig természetes, hogy a szovjet rendszer évtizedei és a rendszerváltozás elhúzódó társadalmi válsága miatt a városi társadalomban a polgári középosztály alig van jelen, s politikai befolyása gyenge.

A városhálózat területi egyenlötlenségei. A városi népesség-változás fentebbi bemutatása is jelezte, hogy a városhálózat jelen átalakulása nemcsak szerkezeti, de földrajzi változásaiban is eléggé szélsőséges. Az egész településhálózat szakadozott. A skála egyik végén egy zömmel apró szemü faluhálózat áll. A falvak átlagos népessége - a 2002. évi népszámlálás adatai szerint - 249 fö́ (Horváth 2008), és csupán 5\%-uknak van 1000 fönél több lakosa. A magyar Alföldéhez hasonló nagyfalvak DélOroszországban s a Volga-vidéken gyakoriak. A faluhálózat leépülése gyors, a 155 ezer 
faluból 13 ezerben egyetlen lakos sem él már (!), csak név maradt a térképen (Zolin 2006). A városhálózaton belül egyértelmúen hanyatlottak a régi iparvárosok; kiemelkedett néhány tudásalapú gazdasággal bíró város (pl. Togliatti, az autógyártás központja). Egyértelmủ nyertesek a területi közigazgatási egységek (oblasztyok) székvárosai, azután Szentpétervár, s mindenekelőtt Moszkva. Az orosz fốváros a globális nagyvárosok közé emelkedett. Itt állítják elö az orosz bruttó hazai termék (GDP) $21 \%$-át. A lakosság foglalkozási szerkezete is megfelel a poszt-indusztriális nagyvárosokénak: 77\%-ukat a szolgáltató szektor foglalkoztatja. A tudásalapú, kreatív ipar jelenléte már gyengébb - ez ma is jórészt a hadiiparhoz kötódik. A moszkvai nagyvárosi régió lakossága meghaladja a 10 millió fớt, a bevándorlás nagyméretủ, a lakáshiány - a jelentôs építkezések ellenére - nyomasztó. Az orosz nagyvárosi hálózat népességméret szempontjából eléggé arányos: Moszkvát a 4,7 millió lakosú Szentpétervár követi, és még 11 városnak van 1 milliónál több lakosa (1. ábra).

\section{1. ÁBRA}

A nagyvárosok földrajzi eloszlása: az Ural-Volga vidéki koncentráció, 2001

(Geographical Distribution of the Big Cities: the Urban Concentration in the Ural-Volga Region, 2001)

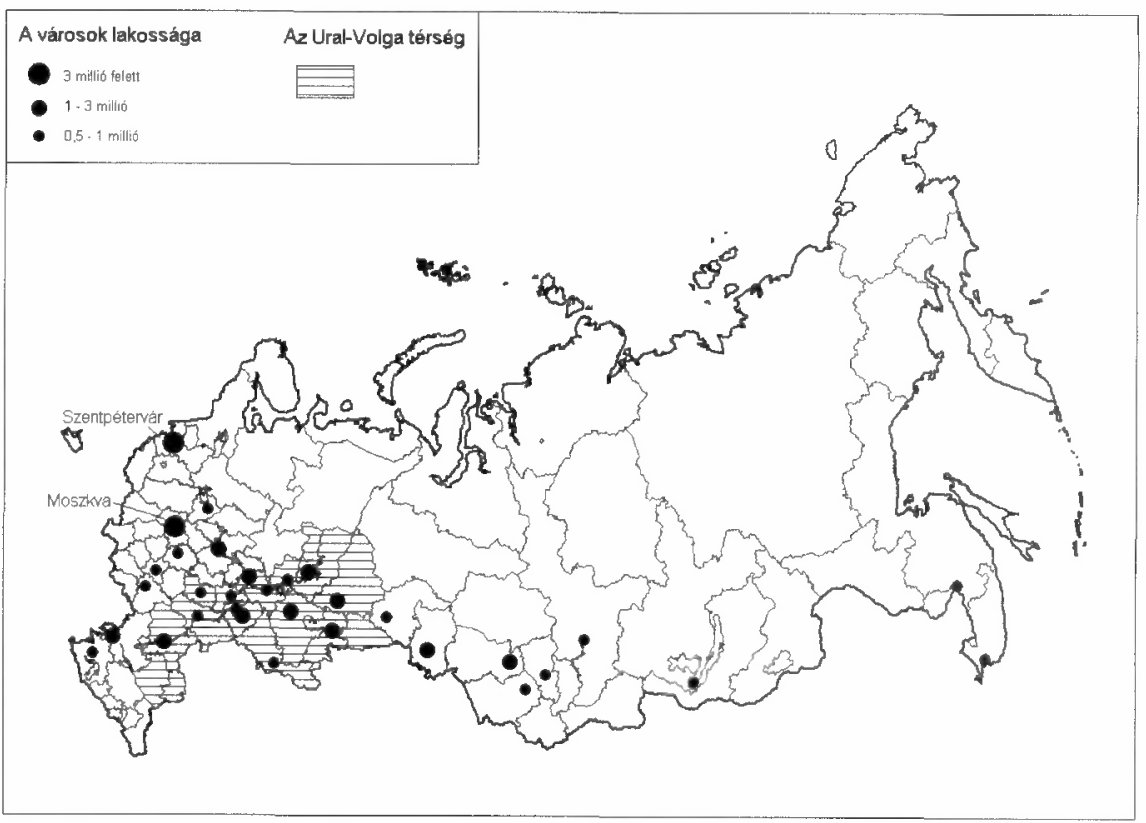

Forrás: Nefjodova-Poljan-Trejvis (2001).

Sajátos vonás, hogy az ország nagy területein nem beszélhetünk valóságos településhálózatról. A sarkvidéki (észak-szibériai) övezetben, az orosz Távol-Kelet nagy részén, a szibériai tajgában (tủlevelü öserdőben) szétszórt városokban (bánya- és ipartelepeken, kikötőkben, katonai telepeken) él a népesség zöme - a városlakók 
aránya több, mint $90 \%$. A városoknak nincs falusi vonzáskörzete, a természeti környezet semmilyen mezőgazdálkodást nem tesz lehetővé. E városoknak egymással is gyér a kapcsolatuk - még városhálózatról sem beszélhetünk -, egyértelmüen távoli - dél-szibériai és európai orosz - városokhoz kötődnek. Ahol még a természeti földrajzi környezet lehetővé tesz némi élelmiszertermelést, néhány városnak van vidéki vonzáskörzete, e „város és vidéke” település-együttesnek kialakulása forditva történt, mint általában Európában: nem a vidék védelmi-igazgatási-szolgáltatási központjaiként emelkedtek ki a városok a falusi települések közül, hanem előbb jöttek létre a városok (pl. mint katonai telepek vagy a távolsági kereskedelem állomásai) s azután próbáltak valami élelmiszer-szolgáltató vidéket kialakítani környékükön.

$\mathrm{Az}$ orosz városok többsége a poszt-szocialista átmenetnek ma is csak kezdeti szakaszában van. Az egy-funkciójú iparvárosok válsága elhúzódónak tủnik. A jelen világgazdasági válság gyorsan megcsapolta a közelmúltban még jelentős orosz tőkefelesleget, mely szinte kizárólag a korábbi magas kőolaj- és földgáz áraknak volt köszönhetö. A válság fékezi újabb orosz nagyvárosok bekapcsolódását a globális városhálózatba. Ma még kockázatos lenne megjósolni, hogy a jövőben az orosz városhálózat erósebben kapcsolódik-e az európai városhálózathoz (amire az elmúlt évtizedben voltak jelek), vagy önálló szereplöje lesz-e a globális versenynek, esetleg megőrizve történelmi különállását. Én ezt az utóbbit valószínúsítem.

\section{Jegyzetek}

$1 \mathrm{Az}$ orosz várostörténelemre vonatkozó legfontosabb forrásaim: Tikhomirov 1959; Hamm 1976; Medvedkov et al. 1993.

2 „Stadtluft macht frei” (a városi levegö szabaddá tesz) - szólt a német mondás.

\section{Irodalom}

Artobolevszkij, Sz.-Borogyina, T.-Glezer, O. (2008) Helyi önkormányzati reform és közigazgatási berendezkedés. - Horváth Gy. (szerk.) Regionális fejlödés és politika az átalakuló Oroszországban. MTA RKK, Pécs. 422-446. o.

Csaba L. (2006) A fólemelkedö Európa. Akadémiai Kiadó, Budapest.

Eisenstadt, S.N.-Shachar, A. (1987) Society, Culture and Urbanization. Sage Publ., Newbury Park, Beverly Hills, London, New Delhi.

Enyedi, Gy. (1984) Az urbanizációs ciklus és a magyar településhálózat átalakulása. Akadémiai Kiadó, Budapest.

Enyedi, Gy. (1988) A városnövekedés szakaszai. Akadémiai Kiadó, Budapest.

Enyedi, Gy (2003) Városi világ - városfejlódés a globalizáció korszakában. PTE, Pécs.

Enyedi, Gy. (2006) A kinai város. - Tér és Társadalom. 4. 1-20. o.

French, R.A.- Ian Hamilton, F.E. (eds.) (1979) The Socialist City. Wiley, New York.

Glazer, O.-Poljana, P. (red.) (2005) Rosszija i eo regionü v 20 veke: territorija, rasszelenyije, migracii. OGI, Moszkva.

Hamm, M.F. (ed.) (1976) The City in Russian History. University Press of Kentucky, Lexington.

Horváth, Gy. (2008) Regionális átalakulás Oroszországban. - Horváth Gy. (szerk.) Regionális fejlódés és politika az átalakuló Oroszországban. MTA RKK, Pécs. 11-63. o.

Lappo, G.M. (1997) Geografija gorodov. Vladosz, Moszkva.

Lappo, G.M.-Poljan, P.M.- Szelǐvanova, I.I. (2007) Aglomeracija v Rosszii v XXI. veke-- Vesztmyik FRRIO. 1. 45-52. o. 
Medvedkov, O.I. (1990) Soviet urbanization. Routledge, London.

Medvedkov, D.- Medvedkov, Y.- Smith, W.R.-Krischunas, M. (1993) Cities of the former Soviet Union. Brunn, S.D. - Williams, J.F. (eds.) Cities of the World. Harper Collins, New York. 151-195. o.

Molodikova, I--Makhrova, A. (2007) Urbanization patterns in Russia in the post-soviet era. - Stanilov, K. (ed.) The Post-Socialist City. Springer, Dortdrecht. 53-70. o.

Nefjodova, T.G.-Poljan, P.M-Trejvis, A. I. (red.) (2001) Gorod i gyerevmya Jevropejszkoj Rosszii: szto let peremen. OGI, Moszkva.

Pacione, M. (2005) Urban Geography: A Global Perspective. Routledge, New York.

Stanilov, K. (2007) The Post-Socialist City. Springer, Dortdrecht.

Taylor, P.J. (ed.) (2004) World City Network. Rutledge, New York.

Tikhomirov, M. (1959) The Towns of Ancient Russia. Foreign Languarge Publishing, Moscow.

Treivish, A.-Brade, I.-Nefedova, T. (1999) Russian cities at the crossroads. - GeoJournal. 1. 115-127. o.

Zolin, P. (2006) Szisztyema szel i poszelenyij. - Ekonomiszt. 2. 76-84. o. 